\title{
COPEPOD DISTRIBUTION IN SURFACE WATERS OF THE DRAKE PASSAGE USING CONTINUOUS PLANKTON RECORDER AND A PUMP-NET ONBOARD SYSTEM
}

\author{
Gustavo Thompson ${ }^{1,2}$, Estela O. Dinofrio ${ }^{3}$, Viviana A. Alder ${ }^{1,2,3}$, Kunio T. Takahashi $^{4}$ and Graham W. Hosie ${ }^{5}$
}

${ }^{1}$ Universidad de Buenos Aires

Departamento de Ecología, Genética y Evolución, Facultad de Ciencias Exactas y Naturales (Ciudad Universitaria Pab. II, Buenos Aires, Argentina)

${ }^{2}$ Consejo Nacional de Investigaciones Científicas y Técnicas

(Rivadavia, 1917, Buenos Aires, Argentina)

${ }^{3}$ Instituto Antártico Argentino

(Cerrito 1248, Buenos Aires, Argentina)

${ }^{4}$ National Institute of Polar Research (10 3 Midori cho, Tachikawa, Tokyo 190 8518, Japan)

${ }^{5}$ Australian Antarctic Division

(203 Channel Highway, Kingston, Tasmania 7050, Australia)

*Corresponding author: gustavo@ege.fcen.uba.ar

\section{A B S TR A C T}

There is no single instrument that can sample quantitatively the complete spectrum of pelagic organisms, or even all the components of zooplankton. Mesh size is the main factor affecting species selectivity in the Continuous Plankton Recorder (CPR), implying a need to use multiple net systems to fully characterize a community. The spatial distribution of copepod communities in the water masses of the western and eastern sectors of Drake Passage were studied using, respectively, a CPR and a Pump Net onboard system. For this purpose, and assuming that copepod community size structures of each of the three water masses were similar in both the sectors studied, the possibility of complementing CPR results using a Pump-Net onboard system was evaluated. The latter system allows the estimation of absolute abundances and has the advantage of solving two problems associated with CPR, namely mesh clogging and low catching efficiency. The contribution of the nauplius forms and species accurately identified with both samplers was analyzed. Although Oithona similis dominated both communities, in the western sector small species made a greater contribution than Calanus simillimus, the opposite being true for the eastern sector. Nauplii and early copepodite stages of $O$. similis were missing from the CPR samples and represented between 69 and $79 \%$ of total copepod communities, whereas small calanoid copepods, C. simillimus copepodites and later stages of $O$. similis were inaccurately sampled by the CPR and represented between 14 and $18 \%$ of the copepod community. Hence, the Pump Net sampler is useful for complementing the semi-quantitative information of the CPR and for its calibration.

\section{RESUMO}

Não há um único instrumento que possa efetuar uma amostragem quantitativa completa para o espectro de organismos pelágicos, ou mesmo, para todos os componentes do zooplâncton. O tamanho da malha é o principal fator que afeta a seletividade de espécies no Registro Contínuo de Plâncton (CPR). Neste trabalho, estudamos a distribuição espacial das comunidades da copépode nas massas de água registradas nos setores ocidentais e orientais da Passagem de Drake, usando um CPR e um equipamento de amostragem que consiste em uma bomba de sucção instalada a uma rede de malha de $20 \mu \mathrm{m}$, respectivamente. Para este fim, e supondo que o tamanho das estruturas da comunidade de Copépodes de cada uma das três massas de água são similares em ambos setores estudados, foi avaliada a possibilidade de complementar resultados obtidos com o uso de CPR usando à bordo o sistema de bomba de sucção-rede. Este sistema permite a avaliação da abundância absoluta e possui a vantagem de resolver dois problemas associados à CPR, que são o assoreamento da rede e a baixa eficiência de captura. A contribuição das formas nauplius e das espécies identificadas com os dois amostradores, foram analisadas. Embora Oithona similis dominasse ambas as comunidades no setor ocidental, pequenas espécies de calanóides apresentaram contribuição mais elevada do que Calanus simillimus, enquanto o inverso foi verdadeiro para o setor oriental. Nauplii e estágios iniciais de copepoditos de $O$. similis faltaram nas amostras de CPR e representaram entre 69-79\% das comunidade total de copépode, enquanto as densidades de pequenos calanódes e copepoditos de $C$. simillimus e estágios posteriores do $O$. similis foram imprecisamente estimadas por meio de CPR e representaram entre 14 e $18 \%$ da comunidade copépodes. Portanto, o sistema de bomba de sucção-rede é útil para complementar informações semi-quantitativas de CPR e sua calibração.

Descriptors: Copepod, Continuous Plankton Recorder, Pump Net sampler, Drake Passage, Southern Ocean.

Descritores: Copépodos, densidade, Registro Contínuo de Plâncton, sistema bomba de sucção, Passagem de Drake, Oceano Antártico. 


\section{INTRODUCTION}

There is no single instrument that can sample quantitatively the complete spectrum of pelagic organisms, or even all the components of the zooplankton (ANON., 1964), which is reflected in the diversity of zooplankton samplers currently in use (WIEBE; BENFIELD, 2003). Mesh size is the main factor affecting plankton selectivity (UNESCO, 1968). The Continuous Plankton Recorder (CPR) has been used as the most effective and rapid method to monitor zooplankton patterns to assess the effects of environmental change (HOSIE et al., 2003). CPR has been used to sample zooplankton since the 1920s (HARDY, 1936), with more than four million miles of CPR tows carried out and with the highest concentration of samplings in the North Sea and Northeast Atlantic (REID et al., 2003). About 190,000 samples have been analyzed under microscopes, the phytoplankton and zooplankton of which have been counted and identified into approximately 500 different taxa (REID et al., 2003). The present understanding of the dynamics of plankton at ocean basin scale, over monthly seasonal cycles and in the time-frame of decennial change, would not have been achieved without the CPR (BRANDER et al., 2003). The Indian and Pacific sectors of the Southern Ocean constitute the second best ocean basin sampled by CPR. In contrast, for the Southern Atlantic Ocean, CPR has provided more limited datasets. Annual CPR tows have been conducted in the Scotia Arc by the British Antarctic Survey and Sir Alister Hardy Foundation for Ocean Science since 2006, but the results have not yet been published. Across the Drake Passage, only four transects have been made (MCLEOD et al., 2010) and detailed analysis of data was only completed for one of these CPR surveys (TAKAHASHI et al., 2010), the results of which were used in this study.

The CPR is an ideal sampler over large scales, with resolution on the 5-10 nautical mile scale, and has been used to demonstrate distinct changes in zooplankton patterns in relation to the various fronts across the Southern Ocean (HOSIE et al., 2003; HUNT; HOSIE, 2005; TAKAHASHI et al., 2010). A mesh size of $270 \mu \mathrm{m}$ has been chosen as appropriate to retain a reasonable proportion of zooplankton (copepods and cladocerans), remaining unchanged over the history of the survey (BATTEN et al., 2003). However, in the last decade, several studies using plankton nets of $100-\mu \mathrm{m}$ mesh size have indicated that small copepods exceed the abundance and sometimes the biomass of larger ones (METZ, 1996; ATKINSON; SINCLAIR, 2000; GALLIENNE; ROBINS, 2001; DUBISCHAR et al., 2002; TURNER, $2004)$. The use of very fine mesh sizes $(<35 \mu \mathrm{m})$ in a high-speed sampler like the CPR has proved impracticable for regular routine use and does not meet the agreed mesh size of $270 \mu \mathrm{m}$ standardized for all CPRs as originally used in 1931. Accurate calibration is difficult to achieve, and there is a large reduction in efficiency (NICHOLS; THOMPSON, 1991), together with an increase in clogging of the mesh net. Mesh size is the main factor affecting species selectivity in CPRs (HUNT; HOSIE, 2006), implying a need to use multiple net systems to fully characterize a community. In spite of this, previous research has compared the sampling efficiency of the $\mathrm{CPR}$ and other more widely used devices using similar mesh nets $(>200 \mu \mathrm{m})$. Most frequent comparisons were with vertical or oblique net hauls (e.g.: CLARK et al., 2001; JOHN et al., 2001; HUNT; HOSIE, 2003; KANE, 2009) and with the Longhurst-Hardy Plankton Recorder (LHPR) (RICHARDSON et al., 2004). In these cases, the possibility of differences in abundance due to changes in the sampling depth cannot be ruled out because of the vertical distribution of zooplankton. Richardson et al. (2004) suggested that a comparison between CPR data and surface data from another sampler over a broader spatial scale would be a more valid approach. Hunt and Hosie (2003) have been the only ones to date who have compared multiple net hauls and CPR samples over the same track with the same mesh over a wide area. Nevertheless, in these studies, the biases due to silk mesh clogging and escape through the mesh of the smaller zooplankton remain unsolved. The rapid increase in the use of CPR data which has occurred over recent years makes it necessary to evaluate the quantitative accuracy of the instrument (JOHN et al., 2001).

Nichols and Thompson (1991) suggested that water samples taken by pump or bottles offer a potential solution to the problem of sampling smaller copepod stages. In order to quantify zooplankton, pump samplers have been used together with zooplankton nets since the 1950s (TONOLLI, 1951) and pump-based samplers have gained popularity in recent years, especially to collect the smaller zooplankton (NAYAR et al., 2002; WIEBE; BENFIELD, 2003). An onboard pump-net sampler allows the collection of micro- and small meso-zooplankton data from a series of horizontal samples over a wide area, making it possible to study mesoscale distribution patterns of zooplankton.

The purpose of the present study was to study the spatial distribution of copepod communities in the water masses of the western and eastern sectors of Drake Passage using a CPR and a Pump-Net onboard system, respectively. For this purpose, the possibility of complementing CPR results in the estimation of the abundance of copepod communities, using a Pump-Net onboard system that addresses the issue of filtering performance, i.e. mesh clogging and escapement through the mesh, was evaluated. 
Biases within the data set

The Drake Passage region under study covers an area of about $600 \times 400$ nautical miles. The possibility of longitudinal differences in copepod abundance or population structures between the western sector (CPR transect) and the eastern sector (pump-net transects) could not be excluded because they were separated by distances ranging from 130 to 470 nautical miles.

The patchy distribution of copepods may give rise to misleading comparison results if the two systems are used simultaneously. A high variability has been found when analyzing simultaneous "replicate" samples from a pump-net sampler and a net sampler separated by only $7 \mathrm{~m}$ (ARON, 1958). All other factors being equal, each sampler would have an equal chance of passing through a patch; then, it would be expected that the counts would vary considerably between the two devices for each paired haul, but that for many paired hauls there would be no trend of one net outfishing the other (ARON, 1958). There is a high degree of variance between replicates even when identical nets are hauled simultaneously on either side of a ship (UNESCO, 1968). The CPR is no exception, as dissimilar results have been obtained when it was compared with other devices with the same mesh size; Hunt and Hosie (2003) found higher densities in CPR samples than in NORPAC net samples.

Sheldon et al. (1972) discovered that the size distribution of marine particles varies predictably with latitude and thus established four zones, each with similar spectra in the Atlantic and Pacific Oceans: Polar, Temperate, Subtropical and Equatorial. They found similar size distribution patterns in samples located south of $50^{\circ} \mathrm{S}$ and between $30^{\circ} \mathrm{W}$ (Atlantic Ocean) and $130^{\circ} \mathrm{W}$ (Pacific Ocean). Other authors later established that the relative abundance of organisms of different sizes (plankton size spectra) can be remarkably consistent within these large regions when ecological conditions are similar (SHELDON et al., 1972; QUINONES et al., 2003). QUINONES et al. (2003) suggested that the planktonic sized-structure of offshore oligotrophic systems (like the region under study) is a conservative property. These authors found similarities between plankton size spectra in places as far apart as the Northwestern Atlantic and the North Pacific Central Gyre. In the Drake Passage, the distributions of sea surface temperature values, primary production values (MOORE; ABBOTT, 2000), SeaWiFS chlorophyll $a$ values (ATKINSON et al., 2008; PARK et al., 2010), transport vectors of drifting particles (THORPE et al., 2007) and zooplankton biomass values (O'BRIEN, 2007) become roughly parallel to the Polar and Subantarctic Fronts, rather than changing with longitude, in waters moving through Drake Passage from the Southeast Pacific Ocean to the Southwestern Atlantic Ocean. In addition, Sprintall (2008), who studied long-term trends and interannual variability of temperature in Drake Passage (from 57 to $67^{\circ} \mathrm{W}$ ) stated that the Polar Front (PF) divides the area into two sub-regions with different dynamics and climatic signals. Sheldon et al. (1972) defined the Antarctic Convergence (Polar Front) as the limit between two zones each with its characteristic particle size structure (Polar and Temperate zones). Based on these previous reports, it seems reasonable to regard both fronts as the strongest spatial structuring forces in the region. So dividing each dataset into three parts according to the positions of the fronts contributes to creating regions of similar environmental conditions in both sectors of Drake Passage: 1) South of the Polar Front (Antarctic Zone; AZ); 2) between the Polar and Subantarctic Fronts (Polar Frontal Zone; PFZ), and 3) north of the Subantarctic Front (Subantarctic Zone; SAZ),

In addition, among marine planktonic invertebrates, copepods may account for $90-97 \%$ of the biomass (BRADFORD-GRIEVE et al., 1999). In the present study, copepods account for about $94 \%$, in term of numbers, of total zooplankton in CPR samples (TAKAHASHI et al., 2010). According to this, it can be inferred that copepod community size structures were rather similar between both sectors of Drake Passage for each water mass analyzed, and that the contribution of small and large size copepods to total community did not differ significantly between sectors. This assumption will be used to evaluate the possibility of complementing CPR results in the estimation of abundance of copepod communities, using a Pump-Net onboard system.

\section{Material and Methods}

Information about the research cruises that study the eastern and western sectors of Drake Passage and a general comparison of the characteristics and methodology of the Pump-Net onboard system and CPR are given in Table 1. For the description, sampling protocol and processing technique of the CPR, see Takahashi et al. (2010), Batten et al. (2003) and Hosie et al. (2003). The western sector of Drake Passage was sampled during the Southern Ocean CPR Survey conducted between $62.31^{\circ} \mathrm{S} 61.77^{\circ} \mathrm{W}$ and $55.76^{\circ} \mathrm{S} 80.01^{\circ} \mathrm{W}$, covering a total of 689.9 nautical miles (nm) between February 7 and 9, 2000. The CPR data of copepods used in this study were collected from tows 68 and 70 (TAKAHASHI et al., 2010). On the other hand, the eastern sector of Drake Passage was covered with two oceanographic transects between 55 and $63^{\circ} \mathrm{S}\left(40-70^{\circ} \mathrm{W}\right)$ during the summer Antarctic Cruise 2000. The first transect was covered between January 3 and 4, 2000 between $55.23^{\circ} \mathrm{S}$ 
$62.57^{\circ} \mathrm{W}$ and $61.65^{\circ} \mathrm{S} 57.38^{\circ} \mathrm{W}$, along a total of $424.39 \mathrm{~nm}$ of which $351.56 \mathrm{~nm}(83 \%)$ were sampled in eight sections of 23-50 nm (mean $44 \mathrm{~nm}$ ). The second transect was made between February 10 and 12,2000 between $55.24^{\circ} \mathrm{S} 65.99^{\circ} \mathrm{W}$ and $60.16^{\circ} \mathrm{S}$ $49.65^{\circ} \mathrm{W}$, covering a total of $601.67 \mathrm{~nm}$ of which 160 $\mathrm{nm}(26 \%)$ were sampled in eight sections of 5-32 nm (mean $25 \mathrm{~nm}$ ). Samples for copepod studies were taken from a continuous pumping system powered by a centrifugal pump placed at $9 \mathrm{~m}$ depth aboard the icebreaker "Almirante Irizar". Seawater was pumped through a natural rubber hose to the wet laboratory. The seawater flow rate was checked before sampling. Up to $3000 \mathrm{~L}$ of seawater were filtered through a modified Nansen $20 \mu \mathrm{m}$-mesh net suspended on the roof and the samples collected were preserved in 3\% formaldehyde. Prior to the laboratory analyses, each microplankton sample was separated into two fractions by using a $300-\mu \mathrm{m}$ mesh net. Absolute abundances of nauplii and some small species of copepods in the fraction $<300 \mu \mathrm{m}$ were estimated from three subsamples of each sample, if enough material was available. Otherwise, the entire sample was examined. Counts were made under an inverted microscope at 200x magnification. Larger copepods (fraction $>300$ $\mu \mathrm{m})$ were identified under a stereoscopic microscope at $40 \mathrm{x}$ magnification and the entire sample was examined.

Table 1. Information on research cruises and characteristics of the Pump-Net system and Continuous Plankton Recorder (CPR).

\begin{tabular}{l|l|l}
\hline \hline Place & \multicolumn{1}{|c}{$\begin{array}{c}\text { Western } \\
\text { Drake Passage }\end{array}$} & $\begin{array}{c}\text { Eastern } \\
\text { Drake Passage }\end{array}$ \\
\hline Cruise name & $\begin{array}{l}8^{\text {th }} \text { Antarctic } \\
\text { expedition } \\
\text { R/V Kaiyo Maru }\end{array}$ & $\begin{array}{l}\text { RH “Alte } \\
\text { Irizar" }\end{array}$ \\
\hline Speed (kn) & $15.22 \pm 1.22$ & $13.6 \pm 1.0$ \\
\hline Date & February 2000 & $\begin{array}{l}\text { January- } \\
\text { February } 2000\end{array}$ \\
\hline $\begin{array}{l}\text { Distance } \\
\text { Sampled } \\
\text { (without frontal } \\
\text { zones) }\end{array}$ & $493 \mathrm{~nm}$ & $511 \mathrm{~nm}$ \\
\hline SAMPLER & CPR Type II & Pump-Net \\
\hline Mesh size & $270 \mu \mathrm{m}$ & $20 \mu \mathrm{m}$ \\
\hline Depth & $6-10 \mathrm{~m}$ & $9 \mathrm{~m}$ \\
\hline Section range & $3.8-3.9 \mathrm{~nm}^{3}$ & $5-50 \mathrm{~nm}$ \\
\hline $\begin{array}{l}\text { Seawater } \\
\text { filtered } \\
\text { per sample }\end{array}$ & $1.13-1.16 \mathrm{~m}^{3}$ & $1.20-3.31 \mathrm{~m}^{3}$ \\
\hline Clogging & Possible & No \\
\hline $\begin{array}{l}\text { Reduction in } \\
\text { flow rate }\end{array}$ & Possible & No \\
\hline
\end{tabular}

The distribution of transects for each cruise in Drake Passage is shown in Figure 1. The positions of the Polar and Subantarctic Front in Drake Passage are defined in accordance with Orsi et al. (1995), using AVHRR Oceans Pathfinder Sea Surface Temperature (SST) data obtained for summer 2000 through the online Physical Oceanography Distributed Active Archive Center (PO.DAAC) Ocean ESIP Tool (POET) at the NASA Jet Propulsion Laboratory, Pasadena, CA, USA (http://podaac.jpl.nasa.gov/poetthe). In the eastern sector of Drake Passage (Pump-Net), samples were not taken in the sections corresponding to the Polar Front and the Subantarctic Front, and hence the corresponding CPR sections in the western sector of Drake Passage (n: 25 and 26, respectively; TAKAHASHI et al., 2010) were not considered in the analyses.

A three-way ANOVA design with fixed factors was used to detect significant fluctuations in density values (ZAR, 1999). Density values were expressed as individuals (ind.) $\mathrm{m}^{-3}$ instead of ind. for each travel section, because the amount of water filtered by the sampler systems per section is different (i.e.: approx. $0.6 \mathrm{~m}^{3}$ for the Pump-Net and $3.11 \mathrm{~m}^{3}$ for the CPR per 10-nautical mile section; JOHN et al., 2002). This has the limitation that the filtration efficiency of the CPR is assumed to remain constant. The analyses of data from both sectors of Drake Passage were run for all copepods and separately only for each copepod species and group identified in both sectors and which contributed, at least $2 \%$ of total abundance. Drake Passage sector (Western and Eastern), Location (Subantarctic Zone and Polar Front Zone) and Time of day (daytime and nighttime) were entered as fixed factors. Samples from the Antarctic Zone were not included in the analysis because no samples were taken during the 8-h nocturnal period in the eastern and western sectors of Drake Passage. The $\ln (\mathrm{X}+1)$ transformation effectively homogenized the variance of the data, except for nauplius stages. On this account, nauplii density values were transformed into ranks and then the ranks were analyzed by a Kruskal-Wallis nonparametric ANOVA (ZAR, 1999). Significant differences in density values were tested using the Tukey's HSD a posteriori multiple-comparison test for unequal sample sizes (ZAR, 1999).

The total length of 1648 copepod specimens recorded in the Pump-Net samples (up to 30 specimens of each species per sample) was measured under a stereoscopic microscope (precision: $0.05 \mathrm{~mm}$ ) and an inverted microscope (precision: $0.015 \mathrm{~mm}$ ). Then, they were separated into 12 size-classes to evaluate total length-frequency (TL-F) distribution of copepods. 


\section{RESUlts}

The SST data determined the presence of three water masses: Antarctic waters south to the Polar Front, the Polar Front Zone between the Subantarctic Front and the PF, and the Subantarctic waters, north to the SAF (Fig. 1). Despite the differences in the total number of sections covered (16 vs. 180), the number of nautical miles in the western sector of Drake Passage was similar to that in the eastern sector (Table 1). For the Antarctic (AZ), Polar Front (PFZ) and Subantarctic (SAZ) Zones, 184, 241 and $87 \mathrm{~nm}$ were studied within the eastern sector, respectively, and 131, 116 and $246 \mathrm{~nm}$ within the western sector, respectively.

The density values of copepods in the western sector of Drake Passage (CPR samples) ranged between 1 and 1710 ind. $\mathrm{m}^{-3}$. A total of 15,575 specimens of copepods were collected (129 sections, without considering the Polar and Subantartic Front sections), of which $70(0.5 \%), 1275(8.1 \%), 3928$ $(25.2 \%)$ and $9993(64.2 \%)$ belonged to nauplius forms, Calanus simillimus, Oithona similis and small calanoid copepods (likely to be adults and copepodites of the more abundant Ctenocalanus citer,
Clausocalanus spp., and the rare Microcalanus pygmaeus, and copepodites of C. simillimus; TAKAHASHI et al., 2010), respectively (Fig. 2). Adults of Rhincalanus gigas and Pleuromamma robusta $(<0.1 \%$ of the total) were also present in the samples. The density values of copepods from the eastern sector of Drake Passage (Pump-Net samples) ranged between 0 and 3040 ind. $\mathrm{m}^{-3}$; data were pooled for further analysis because no significant differences (T-test $0.69, P=0.499$ ) were found between the two oceanographic transects. A total of 4204 copepods, of which 2984 (71\%), 370 (9\%) and 390 (10\%) specimens corresponded to nauplius forms, $C$. simillimus and $O$. similis, respectively, were assigned to 10 species (Fig. 2). Small calanoid copepods (such as C. citer and Clausocalanus spp.), Microsetella norvegica and Oncaea curvata contributed with 5\% and large calanoids such as Calanoides acutus (Calanidae), Metridia gerlachei (Metridinidae) and Subeucalanus longiceps (Eucalanidae) contributed 5\% to the total (Fig. 2). There was variability in the contribution of each copepod category among the three water masses analyzed both in the western and eastern sectors of Drake Passage (Fig. 2).

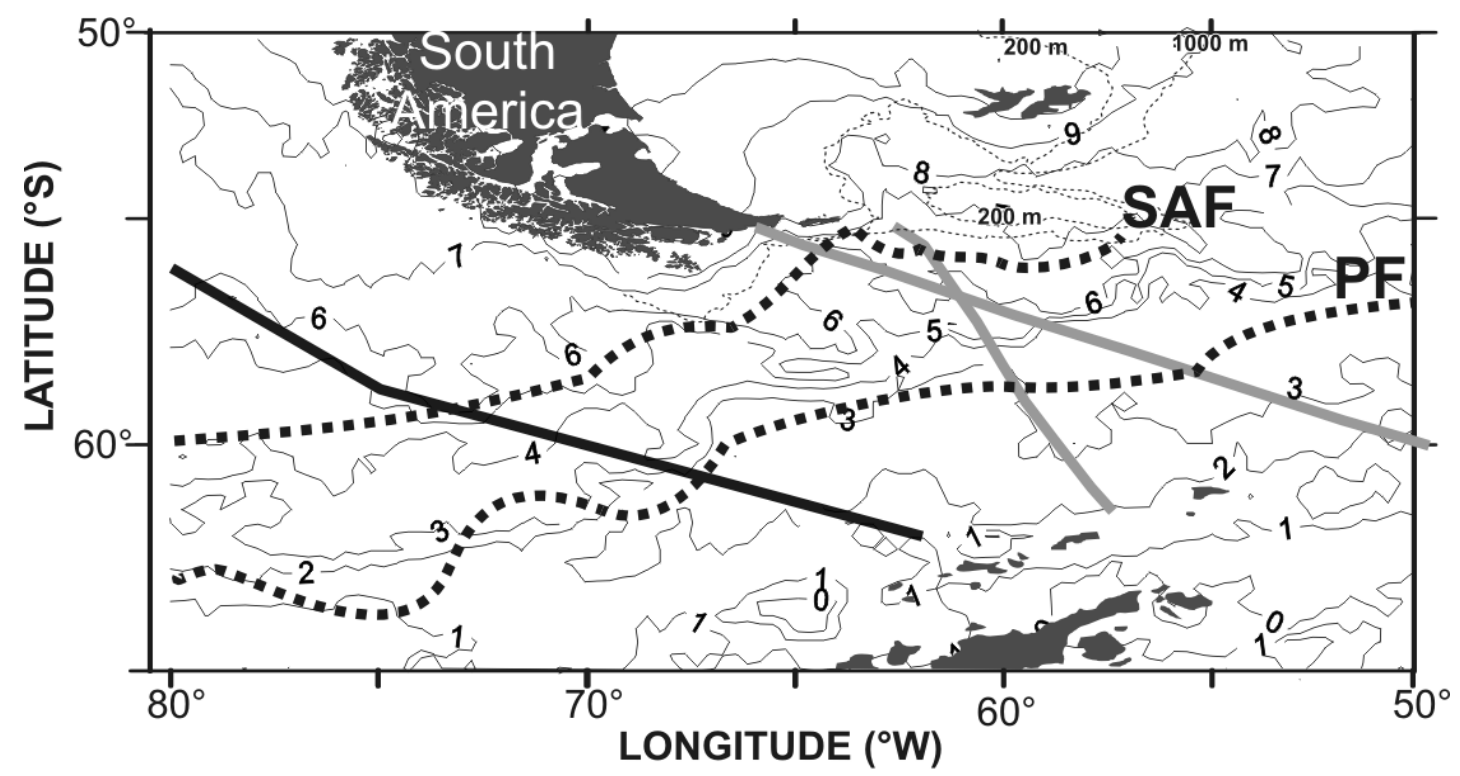

Fig. 1. Transect locations of the Pump-Net system (gray) and Continuous Plankton Recorder (CPR, black) surveys in the eastern and western sectors of Drake Passage during summer 2000. Sea-surface temperature $\left({ }^{\circ} \mathrm{C}\right)$ distributions are also shown. SAF: Subantarctic Front; PF: Polar Front. 


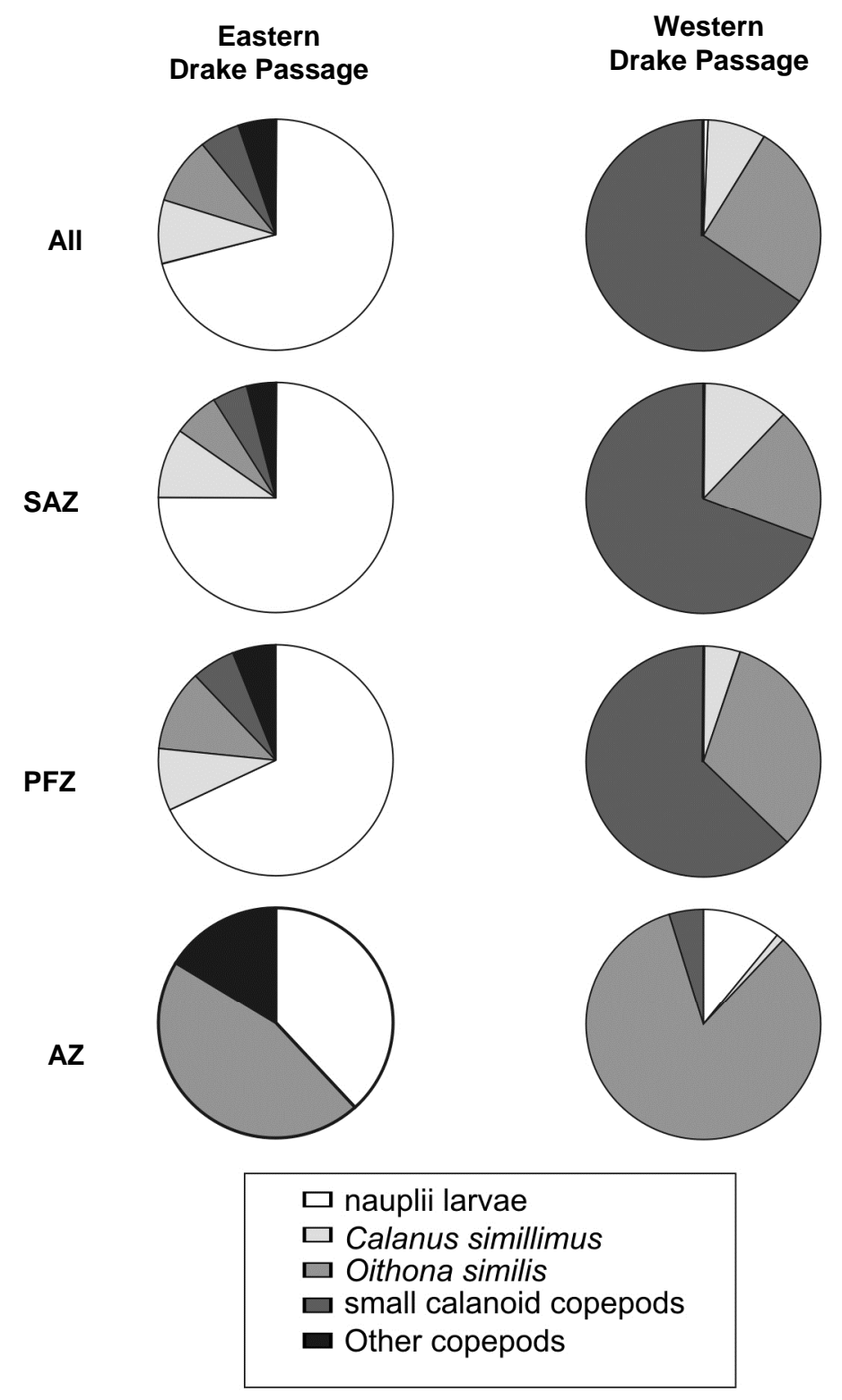

Fig. 2. Comparison of copepod community structures from the eastern and western sectors of Drake Passage compiled from mean density values of each water mass. Small calanoid copepods: copepodites and adults of Ctenocalanus citer and Clausocalanus spp. for both sectors and copepodites of C. simillimus (western). AZ: Antarctic Zone; PFZ: Polar Front Zone; SAZ: Subantarctic Zone.

The density distribution for total copepods, nauplii forms, $O$. similis, $C$. simillimus, $R$. gigas and small calanoid copepodites and copepodsis shown in Figure 3. The density values of total copepods, nauplius larvaeand C. simillimus were significantly higher for the eastern sector of Drake Passage (Table 2, Fig. 3). The mean density values of $R$. gigas nauplii and $O$. similis were slightly higher for the eastern sector than for the western sector of Drake Passage (1.1 and 49 ind. $\mathrm{m}^{-3}$, respectively, vs. 1.0 and 33 ind. $\mathrm{m}^{-3}$, respectively), while the opposite was true for small calanoid copepods (53 and 85 ind. $\mathrm{m}^{-3}$ for the eastern and western sector, respectively), but none of these differences were statistically significant (Table 2, Fig. 3). The distribution of density values of $O$. similis in the western sector of 
Drake Passage showed the presence of extreme values, which could affect ANOVA results. An outlier value from the western sector dataset was detected using Grubbs' test (GRUBBS, 1969), so a further comparison between Drake Passage sectors was made without the outlier, and $O$. similis densities obtained in the eastern sector were significantly higher than those obtained in the western sector $\left(\mathrm{F}_{1,139}=5.67, P=\right.$ $0.018)$. It is worth noting that most differences in copepod density values between eastern and western sectors of Drake Passage were an artifact related to the different sampling systems used, as discussed below.

The main effects of Location and Time of day were significant in some groups (Table 2); the abundances of total copepods, $C$. simillimus, $O$. similis and small calanoid copepods were significantly higher at nighttime than in the daytime. Nauplii of $R$. gigas were more abundant in PFZ than in SAZ. O. similis was the only one showing a significant simultaneous effect of Drake Passage sector and Location; density values were significantly higher in PFZ than in SAZ in the western sector samples, but similar in the eastern sector samples. The Tukey's HSD a posteriori test indicated that the abundances of $C$. simillimus and $O$. similis from the western sector (CPR samples) were significantly higher at nighttime than in the daytime for both PFZ and SAZ $(\mathrm{P}<0.04)$. Although in the eastern sector densities were higher at nighttime than in the daytime, differences were significant for $C$. simillimus (Tukey's HSD, $\mathrm{P}<0.02$ ), but not for $O$. similis (Tukey's HSD, P>0.20).

\section{Discussion}

The mesh selectivity model of Nichols and Thompson (1991) shows that a mesh size of $75 \%$ of the copepod width catches $95 \%$ of all the individuals of that size. Taking into account that the filtering silk of the CPR has a mesh of $270 \mu \mathrm{m}$ and considering the length-to-width formula of Gallienne and Robins (2001), the CPR quantitatively retains copepods of at least 360 in body width and $1250 \mu \mathrm{m}$ in total body length. Experimentally, the rest of the copepods might be caught in different proportions (or undersampled), with values near zero for body lengths below 600-700 $\mu \mathrm{m}$ (NICHOLS; THOMPSON, 1991). Unfortunately, the degree of CPR undersampling is hard to quantify because it would be closely related to the presence of large phytoplankton during the time of sampling. Phytoplankton could decrease the aperture size or porosity of the silk, thus increasing the catching efficiency of small copepods by reducing the possibility of escape through the mesh. At the same time, however, phytoplankton would increase clogging of the filtering silk, reducing the filtration efficiency of the CPR by up to $60 \%$ (HUNT; HOSIE, 2006). Phytoplankton has been observed in the silk only around SAZ (K.T. pers. obs.).

Table 2. Significance (P-levels) of the main effects and interactions of the three-way ANOVAs for the density of each copepod taxon and total copepods. Significant values in bold. Sector: Western and Eastern Drake Passage. Location: Subantarctic and Polar Front Zones. Time of day: daytime and nighttime.

\begin{tabular}{|c|c|c|c|c|c|c|c|}
\hline \multirow[b]{2}{*}{ Taxa } & \multicolumn{7}{|c|}{ Source of variation } \\
\hline & Sector & Location & $\begin{array}{l}\text { Time of } \\
\text { day }\end{array}$ & $\begin{array}{l}\text { Sector } \mathrm{x} \\
\text { Location }\end{array}$ & $\begin{array}{c}\text { Sector } \mathrm{x} \\
\text { Time of day }\end{array}$ & $\begin{array}{l}\text { Location } x \\
\text { Time of day }\end{array}$ & $\begin{array}{c}\text { Sector } \mathrm{x} \\
\text { Location } \mathrm{x} \\
\text { Time of day }\end{array}$ \\
\hline $\begin{array}{l}\text { Calanus } \\
\text { simillimus }\end{array}$ & $<0.0001$ & 0.55 & $<0.0001$ & 0.11 & 0.28 & 0.13 & 0.44 \\
\hline Oithona similis & 0.47 & 0.009 & 0.031 & 0.048 & 0.44 & 0.52 & 0.81 \\
\hline $\begin{array}{l}\text { Nauplii indet } \\
\text { (small) }\end{array}$ & $<0.0001$ & 0.66 & 0.96 & 0.72 & 0.99 & 0.75 & 0.86 \\
\hline $\begin{array}{l}\text { Rhincalanus } \\
\text { gigasnauplii }\end{array}$ & 0.24 & $<0.0001$ & 0.91 & 0.39 & 0.87 & 0.99 & 0.78 \\
\hline $\begin{array}{l}\text { Small calanoid } \\
\text { copepods }\end{array}$ & 0.55 & 0.26 & 0.003 & 0.14 & 0.26 & 0.13 & 0.50 \\
\hline TOTAL & 0.0006 & 0.054 & 0.032 & 0.19 & 0.08 & 0.31 & 0.67 \\
\hline
\end{tabular}



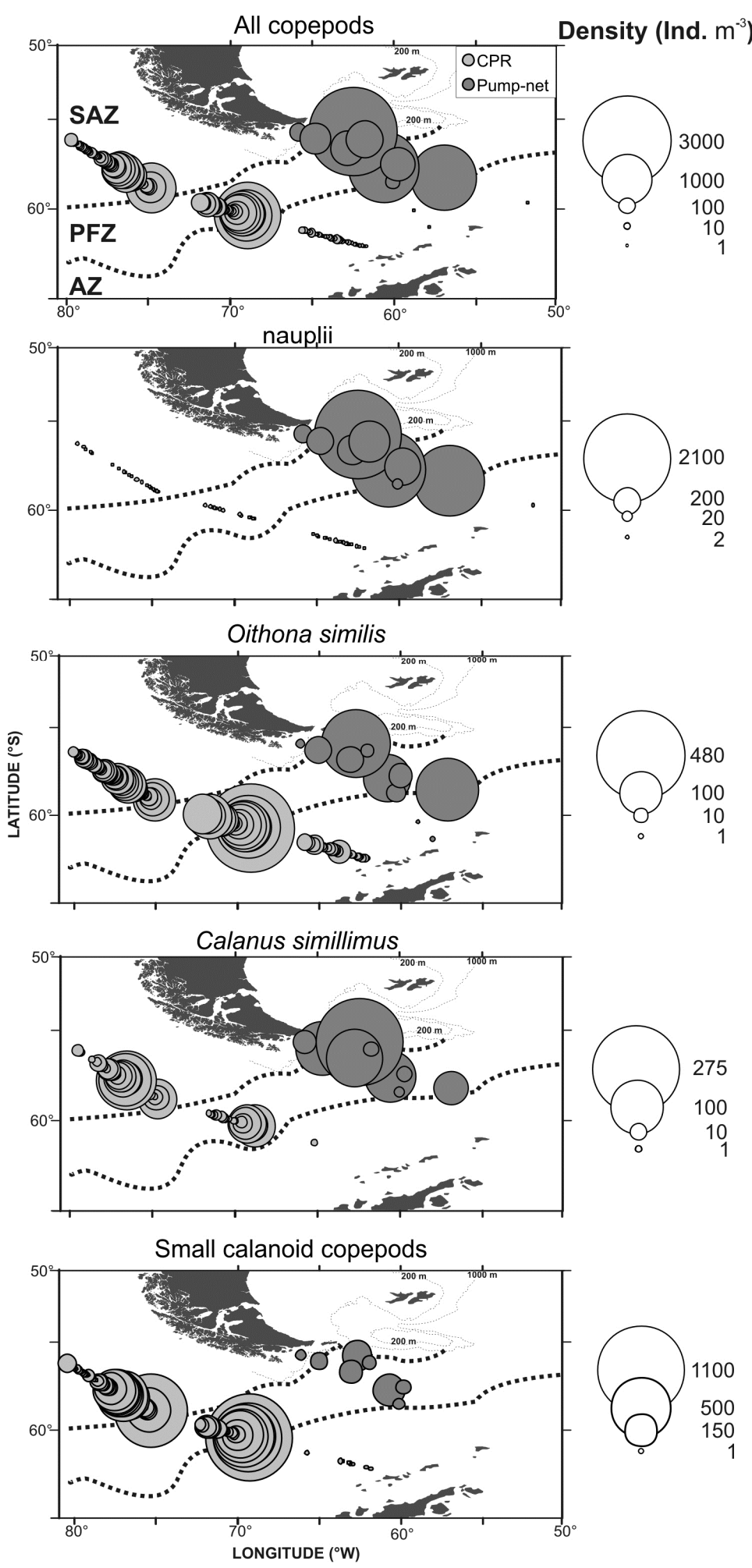

Fig. 3. Density of total copepods, Calanus simillimus, Oithona similis, small calanoid copepods and nauplius forms from Pump-Net and Continuous Plankton Recorder (CPR) samples. The circle size is proportional to absolute density values. AZ: Antarctic Zone; PFZ: Polar Front Zone; SAZ: Subantarctic Zone. 
According to the analysis of total length-frequency (TL-F) distribution of copepods of the on-board pump-net system and assuming similar TL-F distribution structures for the copepod communities in both sectors of Drake Passage (see "Biases within the data set"), approximately $10 \%$ of total copepods were quantitatively caught by the CPR, because they are larger than $1250 \mu \mathrm{m}$ in total length (Fig. 4). In addition, it is likely that about $75 \%$ of the copepod community $(<650 \mu \mathrm{m}$ in total length, Fig. 4$)$ was completely missing from the CPR samples, while $15 \%$ of the copepods probably suffered from some degree of undersampling related to the clogging of the
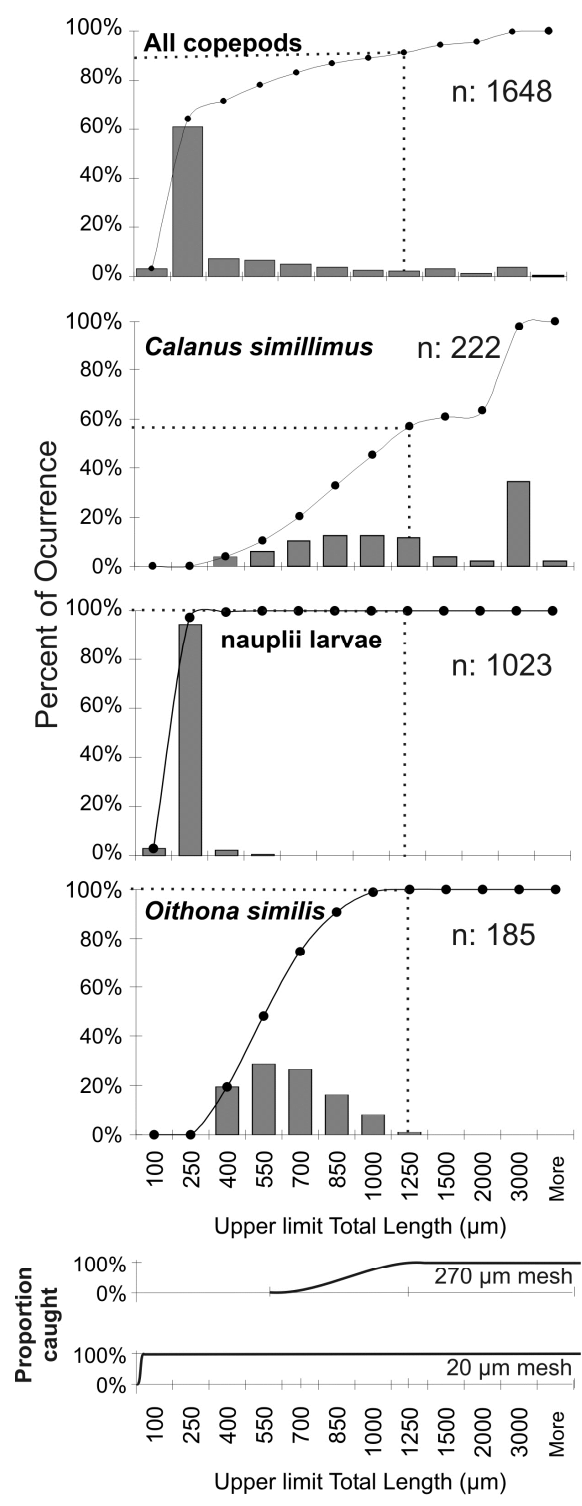

Fig. 4. Size frequency distribution and cumulative frequency distribution of each copepod taxon and total copepods. The proportions of specimens caught with $270-\mu \mathrm{m}$ mesh size (CPR) and 20- $\mu \mathrm{m}$ mesh size (P-N), estimated according to the mesh selectivity model of Nichols and Thompson (1991), and the length-to-width formula of Gallienne and Robins (2001) are also shown. 
Small nauplii provide a clear example of the fact that the pump-net can complement the information obtained from the CPR. They may pass through the $270-\mu \mathrm{m}$ mesh of the CPR due to their small size, and if caught, their identification is often very difficult because of their small size. The copepod dimensions recorded in the present study $(40-220 \mu \mathrm{m}$ in width and 70-650 $\mu \mathrm{m}$ in length) indicate that almost all the small nauplius forms were quantitatively sampled with the $20-\mu \mathrm{m}$ mesh of the on-board pump-net system. There was neither clogging effect nor changes in filtration efficiency. Nauplii showed the highest abundances of all copepod groups considered, with values decreasing southward with increasing body length and width (Figs 4, 5). There has been no previous attempt to quantify nauplius abundances from CPR samples, except for Rhincalanus gigas nauplii, which were quantitatively caught by both devices (Fig. 4). Pitois and Fox (2008) developed a production model for estimating nauplius abundance from that of adult copepods sampled by the CPR. In this model, nauplius abundance is a function of temperature, adult copepod biomass and egg production estimated from fecundity values. Unfortunately, the model lacks the backing of reliable data and contains a number of assumptions and deterministic relationships. In this study, the density values of nauplii may be considered among the highest of an annual cycle, because nauplii reach their maximum abundance in surface waters during summer (VERVOORT, 1965; ATKINSON; SINCLAIR, 2000). Considering that copepod nauplii are, by and large, the main component of small mesozooplankton (WARD et al. 2011), it can be inferred that copepod nauplii in the western sector of Drake Passage (CPR samples) might represent $38 \%, 68 \%$ and $71 \%$ of total copepods for AZ, PFZ and SAZ, respectively, as in the eastern sector (Pump-Net sample).

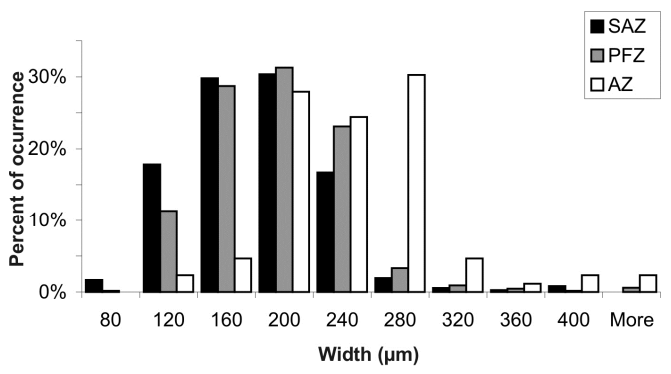

Fig. 5: Width frequency distribution of nauplii from the eastern sector of Drake Passage (Pump-Net samples) for each water mass. AZ: Antarctic Zone; PFZ: Polar Front Zone; SAZ: Subantarctic Zone.

Calanus simillimus is an important species of the Southern Ocean because of its high abundance and biomass (ATKINSON; SINCLAIR, 2000; PAKHOMOV et al., 2000; TAKAHASHI et al.,
2010). The analysis of total length-frequency distribution of $C$. simillimus based on the mesh selectivity model (NICHOLS and THOMPSON, 1991) suggests that copepodites I-IV were undersampled by the CPR and quantitatively sampled by the pump-net sampler (Fig. 4). If some of these early stages were occasionally retained in the CPR mesh, they were difficult to identify and classified as small copepodites. The CPR dataset showed that $C$. simillimus copepodites represent only $0.7 \%$ of $C$. simillimus numbers (G.H. pers. obs.). In pump-net samples, copepodites I-IV represented on average 53\% and $68 \%$ of the $C$. simillimus population for SAZ and PFZ respectively, which is in agreement with previous summer reports that showed older populations north of the Polar Front (WARD et al., 1996). Considering that only $C$. simillimus (CV-CVI) is quantitatively retained by both samplers, this species was somewhat more abundant in the eastern sector (Pump-Net samples; average 52 ind. $\mathrm{m}^{-3}$ and 23 ind. $\mathrm{m}^{-3}$ for SAZ and PFZ respectively) than in the western sector (CPR samples: average 12 ind. $\mathrm{m}^{-3}$ and 16 ind. $\mathrm{m}^{-3}$ for SAZ and PFZ respectively).

For Oithona similis, only stages IV-VI were found in studies using high-speed samplers such as the LHPR or CPR (ATKINSON et al., 1996a,b; PINKERTON et al., 2010). Copepodites I-III might have been missed in CPR samples or, as is the case for nauplii, if any of the copepodites I-III of $O$. similis are trapped on the mesh due to net clogging, then they are difficult to identify accurately due to their small size and the conditions of sampling process. This fraction represents on average $61 \%$ of the $O$. similis population for the three water masses studied (this study, DUBISCHAR et al., 2002). In addition, the on-board pump-net system was expected to quantitatively catch all copepodite stages. Considering only stages IV-VI, $O$. similis was more abundant in the $\mathrm{AZ}$ and $\mathrm{PFZ}$ of the western sector of Drake Passage (average 5 and 72 ind. $\mathrm{m}^{-3}$ respectively against 0.1 and 44 ind. $\mathrm{m}^{-3}$ respectively for the eastern sector). Although similar densities values were recorded for SAZ in both sectors (eastern: 29 ind. $\mathrm{m}^{-3}$ and western: 23 ind. $\mathrm{m}^{-3}$ PumpNet samples), probably this specieswas somewhat more abundant in the western part of SAZ, because it was underestimated. These results are in agreement with the prediction of the boosted regression tree (BRT) model of Pinkerton et al. (2010), which indicated that the median nighttime relative abundance of $O$. similis adults for the longitudinal ranges of the western sector of Drake Passage $\left(65-80^{\circ} \mathrm{W}\right)$ was higher than that for the eastern sector $\left(50-65^{\circ} \mathrm{W}\right)$ during January-February. Moreover, Pinkerton et al, (2010) predicted that an area somewhat to the south of the location of the CPR transect (about $65^{\circ} \mathrm{S}, 80^{\circ} \mathrm{W}$ ), was one of the five hotspots of $O$. similis abundance which deserve further attention. 
Large copepods such as Calanoides acutus and Metridia gerlachei with densities of up to 40-70 ind. $\mathrm{m}^{-3}$ were only caught in the eastern sector of Drake Passage. They are epi- to mesopelagic species (RAZOULS et al., 2005-2011), and their presence has been documented in the study area (Ocean Biogeographic Information System, 2011) and in the Atlantic and Pacific sectors of the Southern Ocean (RAZOULS et al., 2000), where they are among the most numerous calanoid species (SCHNACK-SCHIEL; HAGEN, 1994). On the other hand, the large copepods Rhincalanus gigas and Pleuromamma robusta were found in very low abundances (six and one specimens, respectively) in the western sector (CPR sampler) in samples taken mainly at nighttime; they inhabit deeper waters (mesopelagic-bathypelagic species) and undertake nocturnal migrations (ATKINSON et al., 1996a). These species had lengths over $2 \mathrm{~mm}$, which represents a narrow overlapping with the species recorded in both sectors of Drake Passage. In addition, their lower contribution to the copepod community did not influence the total length-frequency (TL-F) distribution of copepods.

The size range fractions of copepods evaluated and the contribution of each size fraction to the copepod community in each water mass studied are summarized in Table 3. There was a narrow overlapping of the copepod groups found in the lower size range: nauplii were mostly below $400 \mu \mathrm{m}$ length
(Fig. 5, Table 3) and $O$. similis CI-CIII mostly between 400 and $700 \mu \mathrm{m}$. According to pump-net samples, these two groups together represent $66 \%$, $75 \%$ and $79 \%$ of the copepod communities for AZ, PFZ and SAZ, respectively. These two groups were the only copepod specimens in this size range (the harpacticoid Microsetella norvegica was in this size range but its contribution was below 3\%) which were almost completely missing in the CPR samples. Taking into account that copepod community size structures were rather similar in both sectors of Drake Passage, we may suggest that CPR average values of total copepod density for AZ, PFZ and SAZ should be at least multiplied by 3,4 and 5 respectively to obtain a more accurate picture of total copepod abundances. The middle size range was characterized by copepod groups with a wide overlap in their size ranges and represented between 14 and $18 \%$ of the copepod communities analyzed. This fraction was partially underestimated in CPR samples but the degree of undersampling was hard to quantify directly. In spite of this, it may be suggested that the total underestimation of this copepod size fraction in the communities was not significant when compared with the lower size fraction. The higher size fraction was characterized by $C$. simillimus and some other large calanoid species with low densities. Although their contribution to the copepod community was the lowest, they were quantitatively retained by both samplers.

Table 3. Relative contribution of copepod communities, divided into three size ranges, to each water mass analyzed and how well they were characterized with the CPR sampler. AZ: Antarctic Zone; PFZ: Polar Front Zone; SAZ: Subantarctic Zone.

\begin{tabular}{|c|c|c|c|c|c|}
\hline \multirow[b]{2}{*}{ Length size range } & \multirow[b]{2}{*}{ Copepods species / groups } & \multirow[b]{2}{*}{$\begin{array}{l}\text { Characterization with CPR } \\
\text { sampler }\end{array}$} & \multicolumn{3}{|c|}{$\begin{array}{c}\text { Percent of occurrence in copepod } \\
\text { community } \\
\text { (Pump - Net samples) }\end{array}$} \\
\hline & & & $\mathrm{AZ}$ & PFZ & SAZ \\
\hline$<700 \mu \mathrm{m}$ & $\begin{array}{l}\text { Nauplii larvae } \\
\text { Oithona similis(CI-CIII) } \\
\text { Microsetella norvegica }\end{array}$ & Fraction missing & $66 \%$ & $75 \%$ & $79 \%$ \\
\hline $700-1250 \mu \mathrm{m}$ & $\begin{array}{l}\text { Oithona similis }(\mathrm{CIV}-\mathrm{CVI}) \\
\text { Calanus simillimuscopepodites } \\
\text { Small calanoid copepods }\end{array}$ & Fraction underestimate & $18 \%$ & $15 \%$ & $14 \%$ \\
\hline$>1250 \mu \mathrm{m}$ & $\begin{array}{l}\text { Calanus simillimus(adults) } \\
\text { Some adults of small calanoid } \\
\text { copepods } \\
\text { Other large calanoids }\end{array}$ & $\begin{array}{l}\text { Fraction quantitatively } \\
\text { retained }\end{array}$ & $16 \%$ & $10 \%$ & $7 \%$ \\
\hline
\end{tabular}


We may conclude that abundance of copepod communities was dissimilar as between the western and eastern sectors of Drake Passage, and that the same was true for population structure. O. similis dominated both communities with dissimilar distribution among the three water masses of both sectors and its density was higher in the western sector than in the eastern sector of Drake Passage. Small calanoid copepods (Clausocalanus spp., Ctenocalanus citer) had a higher contribution than $C$. simillimus in the western sector, while the opposite was true for the eastern side. Although the Pump-Net is not an autonomous system, it allows the estimation of absolute abundances and has the advantage of solving two problems associated with the use of CPR, namely mesh clogging when phytoplankton are recorded and low catching efficiency of small zooplankton through the $270-\mu \mathrm{m}$ mesh. Nauplii and early copepodite stages of calanoid and cyclopoid species which were inaccurately sampled by the CPR were possible to quantify with the on-board pump-net sampler. Hence, the pump-net sampler is useful for complementing the semi-quantitative information from the CPR and for its calibration when used in the Southern Ocean. The comparative study of these two kinds of gear should be performed on a 1-year cycle because the retention efficiency of zooplankton is seasonally dependent (RICCARDI, 2010).

\section{ACKNOWLEDGEMENTS}

We are grateful to the SCAR Southern Ocean CPR Survey for supplying the CPR data, and to the personnel of the Instituto Antártico Argentino (IAA), the Servicio de Hidrografía Naval and the crew of "Almirante Irizar" for their help during sampling. We also thank Prof. L. Fransozo and J. Zanguettin Pereira for checking the Portuguese grammar and syntax of the Resumo. Financial support for Summer Antarctic Cruises was provided for V. Alder by the IAA and the Agencia Nacional de Promoción Científica y Tecnológica (ANPCyT), grants 58 IAA and PICT 7-9108 ANPCyT.

\section{REFERENCES}

ANON. VI: Sampling zooplankton to determine biomass. In Recommended interim procedures for measurements in biological oceanography. Prepared by Biological Methods Panel Committee on Oceanography. Washington, D.C.: Nat. Acad. Sci.-Nat. Res. Coun., 1964. p. 17-23.

ARON W. The use of large capacity portable pump for plankton sampling, with notes on plankton patchiness. J. Mar.Res., v. 16, p. 158-173, 1958.

ATKINSON, A.; WARD, P.; MURPHY, E. J. Diel periodicity of Subantarctic copepods: relationships between vertical migration, gut fullness, and evacuation rate. J. Plankton Res., v. 18, p. 1387-1405, 1966a.

ATKINSON, A.; SHREEVE, R. S.; PAKHOMOV, E. A.; PRIDDLE, J.; BLIGHT, S. P.; WARD P. Zooplankton response to a phytoplankton bloom near South Georgia, Antarctica. Mar. Ecol. Prog. Ser., v. 144, p. h195-210, $1996 b$.

ATKINSON, A.; SINCLAIR, J. D.. Zonal distribution and seasonal vertical migration of copepod assemblages in the Scotia Sea. Polar Biol., v. 23, p. 46-58, 2000.

ATKINSON, A.; SIEGEL V.; PAKHOMOV, E. A.; ROTHERY, P.; LOEB, V.; ROSS, R. M.; QUETIN L. B.; SCHMIDT, K.; FRETWELL, P.; MURPHY, E. J.; TARLING, G. A.; FLEMING, A. H. Oceanic circumpolar habitats of Antarctic krill. Mar. Ecol. Prog. Ser., v. 362, p. 1-23, 2008.

BATTEN, S. D.; FLINKMAN, J.; HAYS, G.; JOHN, G.; JOHN, A. W. G.; JONAS, T.; LINDLEY, J. A.; STEVENS, D. P.; WALE, A. CPR sampling: the technical background, materials and methods, consistency and comparability. Prog. Oceanogr., v.58, p. $193-215,2003$.

BRADFORD-GRIEVE, J. M.; MARKHASEVA, E. L.; ROCHA, C. E. F.; ABIAHY, B.. Copepoda. In: BOLTOVSKOY, D. (Ed.). South Atlantic Zooplankton. v.2. Leiden: Backhuys Publishers, 1999. p. 869-1098.

BRANDER, K. M.; DICKSON, R. R.; EDWARDS, M. Use of Continuous Plankton Recorder information in support of marine management: applications in fisheries, environmental protection, and in the study of ecosystem response to environmental change. Prog. Oceanogr., v. 58, p. 175-191, 2003.

CLARK, R. A.; FRID, C. L. J.; BATTEN, S.. A critical comparison of two long-term zooplankton time series from the central-west North Sea. J. Plankton Res., v. 23, p. 27-39, 2001.

DUBISCHAR, C. D.; LOPES, R. M.; BATHMANN, U. V. High summer abundances of small pelagic copepods at the Antarctic Polar Front - implications for ecosystem dynamics. Deep-Sea Res. PT II, v. 49, p. 3871-3887.

GALLIENNE C. P.; ROBINS, D. B.. Is Oithona the most important copepod in the world's oceans? J. Plankton Res., v. 23, p. 1421-1432, 2001.

GRUBBS, F. E. Procedures for detecting out-lying observations in samples. Technometrics, v. 11, p. 1-21, 1969.

HARDY, A. C. Observations on the uneven distribution of oceanic plankton. Discov. Rep., v. 11, p. 511- 538, 1936.

HOSIE, G. W.; FUKUCHI, M.; KAWAGUCHI, S.. Development of the Southern Ocean Continuous Plankton recorder survey. Prog. Oceanogr., v. 58, p. 263-28, 2003..

HUNT, B. P. V.; HOSIE, G. W. The Continuous Plankton Recorder in the Southern Ocean: a comparative analysis of zooplankton communities sampled by the CPR and vertical net hauls along $140^{\circ}$ E. J. Plankton Res., v. 25, p. 1561-1579, 2003.

HUNT, B. P. V.; HOSIE G. W. Zonal structure of zooplankton communities in the Southern Ocean south of Australia: results from a $2150 \mathrm{~km}$ Continuous Plankton Recorder transect. Deep-Sea Res., v. 52, p. 1241-1271, 2005 . 
HUNT, B. P. V.; HOSIE, G. W. Continuous Plankton Recorder flow rates revisited: clogging, ship speed, and flowmeter design. J. Plankton Res., v. 28:847-855, 2006.

JOHN, E. H.; BATTEN S. D.; HARRIS R.P.; HAYS G. C. Comparisons between zooplankton data collected by the Continuous Plankton Recorder survey in the English Channel and by WP-2 net at station L4, Plymouth (UK). J. Sea Res. , v. 46, p. 223-232, 2001.

JOHN, E. H.; BATTEN, S. D.; STEVENS, D. S.; WALNE, A. W.; JONAS, T. J; HAYS, G. C. Continuous Plankton Records stand the test of time: evaluation of flow rates, clogging and the continuity of the CPR time-series. $\mathbf{J}$. Plankton Res. , v. 24, p. 941-946, 2002.

KANE, J. A comparison of two zooplankton time series data collected in the Gulf of Maine J. Plankton Res., v. 31:, p. $-259,2009$.

MCLEOD, D. J.; HOSIE, G. W.; KITCHENER, J. A.; TAKAHASHI, K. T.; HUNT, B. P. V. Zooplankton Atlas of the Southern Ocean: The SCAR SO-CPR Survey (1991-2008). Polar Sci., v. 4, p. 353-385, 2010.

METZ, C. Life strategies of dominant Antarctic Oithonidae (Cyclopoida, Copepoda) and Oncaeidae (Poecliostomatoida, Copepoda) in the Bellinghausen Sea. Ber. Polarforsch., v. 207, p. 1-123, 1996.

MOORE, J. K.; ABBOTT, M. R. Phytoplankton chlorophyll distributions and primary production in the Southern Ocean. J. Geophys. Res., v. 105 , p. 28709-28722, 2000.

NAYAR, S.; GOH, B. P. L. and CHOU, L. M.. A portable, low-cost, multipurpose, surface-subsurface plankton sampler. J. Plankton Res., v. 24, p. $1097-$ $1105,2002$.

NICHOLS, J. H.; THOMPSON, A. B.. Mesh selection of copepodite and nauplius stages of four calanoids copepod species. J. Plankton Res., v. 13, p. 661-671, 1991.

OCEAN BIOGEOGRAPHIC INFORMATION SYSTEM. <www.iobis.org>. Accessed April 22nd, 2011.

O'BRIEN, T. D. 2007. COPEPOD: The Global Plankton Database. A review of the 2007 database contents and new quality control methodology. U.S. Dep. Commerce, NOAA Tech. Memo. NMFS-F/ST-34, $28 \mathrm{p}$.

ORSI, A. H.; WHITWORTHIII, T.; NOWLIN JR.,W. D. On the meridional extent and fronts of the Antarctic circumpolar current. Deep-Sea Res. PT I, v. 42, p. 641673, 1995.

PAKHOMOV, E. A.; ANSORGE, I. J.; FRONEMAN, P. W. Variability in the inter-island environment of the Prince Edward Islands (Southern Ocean). Polar Biol. v. 23, p. 593-603, 2000.

PARK J.; Oh, I.-S.; KIM, H.-C.; YOO, S. Variability of SeaWIFS chlorophyll-a in the southwest Atlantic sector of the Southern Ocean: Strong topographic effects and weak seasonality. Deep-Sea Res., PT I v. 57, p. 604620,2010

PINKERTON, M. H.; SMITH, A. N. H.; RAYMOND, B.; Hosie, G. W.; SHARP, B.; LEATHWICK, J. R.; BRADFORD-GRIEVE, J. M.. The spatial and seasonal distribution of Oithona similis in the Southern Ocean: predictions using Boosted Regression Trees. Deep-Sea Res. PT I. v. 57, p 469-485, $2010 .$.
PITOIS, S. G.; FOX, C. J. Empirically cod larvae in modelling the potential effects of changes in temperature and prey availability on the growth of UK shelf seas. ICES J.Mar.Sci., v. 65:1559-1572, 2008.

QUINONES, R. A.; PLATT, T.; RODRÍGUEZ, J. Patterns of biomass-size spectra from oligotrophic waters of the Northwest Atlantic. Prog. Oceanogr., v. 57, p. 405-427, 2003.

RAZOULS, S.; RAZOULS, C.; DE BOVÉE, F. Biodiversity and biogeography of Antarctic copepods. Antarct. Sci., v. 12, p. 343-362, 2000.

RAZOULS, C.; DE BOVÉE, F.; KOUWENBERG, J. AND DESREUMAUX, N. Diversité et répartition géographique chez les Copépodes planctoniques marins. 2005-2011. http://copepodes.obs-banyuls.fr.

REID P. C.; COLEBROOK, J. M.; MATTHEWS, J. B. L.; AIKEN, J. CONTINUOUS PLANKTON RECORDER TEAM. The continuous plankton recorder: concepts and history, from plankton indicator to undulating recorders. Prog. Oceanogr. 58:117-173, 2003.

RICCARDI, N. Selectivity of plankton nets over mesozooplankton taxa: implications for abundance, biomass and diversity estimation. J. Limnol., v. 69, p. 287-296, 2010

RICHARDSON, J. A.; JOHN, H. E.; IRIGOIEN, X.; HARRIS, P. R.; HAYS, C. G. How well does the Continuous Plankton Recorder (CPR) sample zooplankton? A comparison with the Longhurst Hardy Plankton Recorder (LHPR) in the northeast Atlantic. Deep-Sea Res. PT I, v. 51, p. 283-1294, 2004.

SCHNACK-SCHIEL, S. B.; HAGEN, W. Life cycle strategies and seasonal variations in distribution and population structure of four dominant calanoid copepod species in the eastern Weddell Sea, Antarctica. J. Plankton Res., v. 16, p. 1543-1566, 1994.

SHELDON, R. W.; PRAKASH, A. SUTCLIFFE JR., W. H. The size distribution of particles in the ocean. Limnol. Oceanogr., v. 17, p. 327-340, 1972.

SPRINTALL, J.. Long term trends and interannual variability of temperature in Drake Passage. Prog. Oceanogr., v.77, p. 316-330, 2008.

TAKAHASHI, K. T.; KAWAGUCHI, S.; HOSIE, G. W.; TODA, T.; NAGANOBU, M.; FUKUCHI, M.. Surface zooplankton distribution in Drake Passage recorded by Continuous Plankton Recorder (CPR) in late austral summer of 2000. Polar Sci., v. 3, p. 235-245, 2010.

THORPE, S. E.; MURPHY, E. J.; WATKINS, J. L. Circumpolar connections between Antarctic krill (Euphausia superba Dana) populations: investigating the roles of ocean and sea ice transport. Deep-Sea Res. PT I, v. 54, p. 792-810, 2007.

TONOLLI V. A new device for continuous quantitative plankton sampling: the plankton bar. Proc. Int. Assoc. Theor., v. 11, p. 422-429, 1951.

TURNER, J. T. The importance of small planktonic copepods and their roles in pelagic marine food webs. Zool. Stud., v. 43 , p. $255-266,2004$.

UNESCO. Zooplankton Sampling Monographs on Oceanographic Methodology, n 2. Paris: UNESCO Press, 1968. $174 \mathrm{p}$.

VERVOORT, W. Notes of the biogeography and ecology of freeliving, marine Copepoda. In:VAN OYE P.; VAN MIEGHAN J. (Ed.) Biogeography and ecology in Antarctica. The Hague: Junk, 1965. p. 381-400. 
WARD, P.; SHREEVE, R. S.; CRIPPS, G. C.; TRATHAN, P. N. Mesoscale distribution and population dynamics of Rhincalanus gigas and Calanus simillimus in the Antarctic Polar Open Ocean and Polar Frontal Zone during summer. Mar. Ecol. Prog. Ser., v. 140, p. 21-32, 1996.

WARD, P.; ATKINSON, A.; TARLING, G.. Mesozooplankton community structure and variability in the Scotia Sea: A seasonal comparison. Deep Sea Res. PT II, v. 59-60, p. 78-92, 2011.
WIEBE, P. H.; BENFIELD, M. C. From the Hensen net toward four-dimensional biological oceanography. Prog. Oceanogr., v. 56, p. 7-136, 2003.

ZAR, J. H. Biostatistical Analysis. 4th ed. Englewood Cliffs, NJ.:Prentice-Hall, 1999.

(Manuscript received 26 October 2011; revised 22 July 2012; accepted 14 August 2012) 